\title{
The Union Makes the Road
}

\author{
Milagrosa Olmedo Alguacil* \\ Nursing, Spain \\ *Corresponding author: Milagrosa Olmedo Alguacil, Nursing, Vicedecana de Ordenación Académica, Spain
}

Submission: 㘹February 22, 2018; Published: 海 February 27, 2018

\section{Editorial}

Engineering have been part of life since always, the construction of the wheel was a milestone in the advancement of societies, and the use of fire in the preparation of food products. Each era is marked by social and paradigmatic movements that make that they are special.

Always come preceded of others or are precursors that will come. At the present time are shared paradigms in different disciplines and this makes each of these reinforce the knowledge learned and shared. Health Sciences now have great support in the engineering and inventions that occurred to other sciences or disciplines have been doomed in these.

We must put at the disposal of the scientific community the discoveries and support generated, although they are minimal, since they will be essential for the progress of all science. The knowledge generated is given through scientific journals that can be as it is the case of this, multidisciplinary, where different disciplines can write scientific articles and that they are editing on many occasions it is difficult because the requirements of the magazines seem insurmountable, when you have to do is write and learn from failures and signs that give us in the event of rejection. Other times, the problem is because it does not have sufficient knowledge of English and who makes the article isn't in a research group that covers translation costs. However, it is essential you try over and over again for the introduction in the scientific ranking.

In the branch of knowledge which I work: Health Sciences, is very important to not forget the person healthy or sick, because she is one of the primary sources of data that we need to know. However, this person it can help, cure, care, strengthen, support, etc., with many and different mechanisms based on developed scientific knowledge ranging from little things like infusoras of liquid bombs, up to le resonance magnetic Proton to verify clinical suspicion of a patient. Currently the health sciences could not be understood without the support that are from engineering. In the last thirty years have both changed hospital procedures that today is not acting without the support engineers.

By way of example, patients who are bedridden in bed and have some disease that prevents them from mobility, tend to slip to the foot of the bed when they are bedridden, causing decubitus ulcers through shear, pressure, and friction it occur between the connected tissues. There are several mechanisms created by engineers so that this damage does not occur or is slow. However, health sciences, mechanical and electronic engineering so that the mechanisms that exist in the market are more comfortable in the use and management by persons who operate more joint from different disciplines, namely, physical, research is needed so more would use it and their use would be more widespread so it is looking for two things: comfort in use and easy to use. Not that today design is intended to be used in large spaces and very specific non-hospital patients. In the hospital this is difficult to manage.

You must advance in scientific knowledge to believe new products and materials that contribute to the health sciences new goals in the treatment of patients, without abandoning the existing which can be improved to the same goal of the new: provide knowledge. This must be validated by the scientific and multidisciplinary community. All wemust echo, because everyone wins. The architects of that knowledge expands are the editors of scientific journals, the scientific community must be hand to achieve new goals, where to expand the capacities of the researchers as well as move in the plane of knowledge towards the interest: interest that my project, interest in which I know is known to me, and interest in learning about other draft. That is why it is so important that multidisciplinary journals as it is that we are concerned are not lost and are arising in the difficult world of the JCR.

Is obvious, that the road to it improvement only is can make working in lines of inclusion among the different Sciences and worlds scientific. The actors of the scientific works are the inventors and towards which are aimed. 
(c) (P) Creative Commons Attribution 4.0 International License

For possible submissions Click Here

Submit Article

\section{Your subsequent submission with Crimson Publishers} will attain the below benefits

- High-level peer review and editorial services

- Freely accessible online immediately upon publication

- Authors retain the copyright to their work

- Licensing it under a Creative Commons license

- Visibility through different online platforms

- Global attainment for your research

- Article availability in different formats (Pdf, E-pub, Full Text)

- Endless customer service

- Reasonable Membership services

- Reprints availability upon request

- One step article tracking system 